\title{
Use of botulinum toxin type a in temporomandibular disorder
}

\author{
Utilização da toxina botulínica tipo a na disfunção temporomandibular
}

\author{
Mary Akemy Uehara HUAMANI ${ }^{1}$ \\ Luciano Artioli MOREIRA² \\ Ney Soares de ARAÚJO' \\ Marcelo Henrique NAPIMOGA ${ }^{1}$ \\ José Luiz Cintra JUNQUEIRA' \\ Milton Edson MIRANDA'
}

\begin{abstract}
Temporomandibular disorder (TMD) may be defined as a set of clinical scenarios involving the masticatory muscles, the temporomandibular joint (TMJ) and associated structures. Currently, 40 to 75\% of the population has some sign of temporomandibular disorder, mainly pain located in the muscles of mastication in the pre-auricular region. The present clinical case was diagnosed as muscle temporomandibular disorder secondary to parafunction, as well as muscle hyperactivity due to surgical displacement of the left temporal muscle on two occasions, one for placement of aneurysm clips and the other for tumor excision from the supraorbital region on the left side. The patient sought medical and dental attention for 10 years due to constant headaches, tiredness and pain in the cheeks. The patient tried numerous bite-guards and pharmacological therapies to no avail. The American Academy of Orofacial Pain Questionnaire was applied combined with the Criteria for Research and Diagnostics (DRC) and a decision was made to use botulinum toxin type $A$ in the masseter and temporalis muscles. An analog pain scale was applied over 90 days. Three days following the application of botulinum toxin type $A$, the patient reported a significant improvement with complete resolution of pain (level 0) after 90 days. At 12 weeks from starting treatment, facial muscle physiotherapy was introduced to strengthen the muscles of mastication and the patient remained pain-free, which allowed the preparation and adaptation of a snap-on prosthetic appliance. In conclusion, the use of botulinum toxin in patients with temporomandibular disorder should be considered as a viable therapeutic option.
\end{abstract}

Indexing term: Botulinum toxins, type A. Dentistry. Temporomandibular joint disorders.

\section{RESUMO}

A desordem temporomandibular pode ser definida como um conjunto de distúrbios que envolvem os músculos mastigatórios, a articulação temporomandibular e estruturas associadas. Atualmente entre 40 a $75 \%$ da população apresenta algum sinal de desordem temporomandibular, sendo o mais frequente a dor, principalmente localizada nos músculos da mastigação e na região pré-auricular. O caso clínico apresentado foi diagnosticado como desordem temporomandibular muscular por parafunção, hiperatividade muscular antecedida por deslocamento do músculo temporal esquerdo para realização de duas cirurgias, uma para colocação de clips aneurismático e a outra para remoção de um tumor na região supraorbitária do lado esquerdo. A paciente procurou durante 10 anos ajuda médica e odontológica por sofrer com constantes dores de cabeça, cansaço, dor nas bochechas, usou inúmeras placas, medicamentos, porém o efeito desejado nunca fora alcançado. Frente ao histórico foi aplicado o questionário da Academia Americana de Dor Orofacial e o Critério de Pesquisa e Diagnóstico (RDC), e a conduta clinica adotada foi à aplicação de toxina botulínica tipo A nos músculos masseter e temporal. Foi aplicada uma escala de dor analógica ao longo de 90 dias. Já após 3 dias da aplicação da toxina botulínica tipo A, a paciente relatou melhora significativa chegando a nível 0 de dor após 90 dias. Após 12 semanas do início do tratamento, foram acrescidos exercícios para fortalecimento dos músculos da mastigação, sendo que a paciente continuava sem dor, permitindo desta forma a confecção e instalação de prótese tipo Snap-on. Desta forma, o emprego da toxina botulínica em pacientes com desordem temporomandibular deve ser considerado como uma boa opção terapêutica.

Termos de indexação: Toxinas botulínicas tipo A. Odontologia. Transtornos da articulação temporomandibular.

\section{INTRODUCTION}

Temporomandibular dysfunction (TMD) is defined as a set of disorders involving the masticatory muscles, the temporomandibular joint (TMJ) and associated structures $^{1-2}$, the main related signs and symptoms are pain, tenderness to palpation in both masticatory muscles and temporomandibular joint (TMJ), joint sounds and changes to mandibular dynamics ${ }^{1-4}$. The etiology of TMD is multifactorial, with bruxism being involved with both onset and/or perpetuation of some disorders ${ }^{5-6}$. Diagnosis and treatment are often challenging, therefore early management should preferably be minimally invasive, reversible and conservative ${ }^{7}$, such laser therapy, biteguards, anti-inflammatories and painkillers, muscle relaxants, stretching techniques ${ }^{8-10}$.

The use of botulinum toxin type A (BTX-A) was officially approved in Brazil for use in dentistry in 2014

1 Instituto de Pesquisas São Leopoldo Mandic, Laboratório de Imunologia e Biologia Molecular. Rua José Rocha Junqueira, 13, 13045-755, Campinas, SP, Brasil. Correspondência para / Correspondence to: MH NAPIMOGA. E-mail: marcelo.napimoga@gmail.com.

2 Associação Paulista de Cirurgiões-Dentistas. São Paulo, SP, Brasil. 
(resolution CFO-145), which permitted the incorporation of this additional form of treatment for TMD. BTX-A is a protein derived from the anaerobic bacterium Clostridium botulinum and has been introduced as a therapeutic method for TMD due to its potent muscle relaxant properties (paralyzes muscles) with very few side effects ${ }^{11}$. The toxin inhibits the release of acetylcholine at the neuromuscular junction, causing muscle paralysis and, consequently, muscle relaxation ${ }^{12-15}$ for 8 to 16 weeks $^{16}$. The indications for BTX-A are mostly focused on excessive or inappropriate movement during muscle contraction, however, due to its pharmacological effects and proposed mechanisms of action, further applications have been considered. Studies have also shown that this neurotoxin plays a role on reducing the release of inflammatory mediators (calcitonin, substance $P$ and glutamate) that cause pain. For this reason, BTX-A is effective in reducing muscle pain and some types of headaches ${ }^{17-21}$.

In a study of patients with chronic pain resulting from hyperactivity of the muscles of mastication, parafunctional movements and hypermobility disorders, considerable improvement (91\%) was shown with the use of BTX-A ${ }^{21}$, corroborating the effectiveness of this method on tackling facial pain associated to chronic muscle hyperactivity in patients that do not respond to conventional treatment approaches ${ }^{22}$. A study with patients diagnosed with bruxism and myofascial pain in the muscles of mastication reported a significant improvement in the range of mandibular movements as well as in pain levels, both at rest and during mastication ${ }^{23}$ after using BTX-A. Some evidence suggest the analgesic effect of the toxin is often more important than its effect on motor control, which may explain the pain relief reported in syndromes that are unrelated to muscle spasm ${ }^{24-28}$.

Side effects of TBX-A, such as nausea, dysphagia, allergy or the feeling of having caught a cold are transient and tend to disappear within a few days of application ${ }^{11,29-30}$. Treatment with botulinum toxin is, however, contraindicated in patients with myasthenia gravis as well as pregnant and lactating women, Lambert Eaton syndrome, acquired autoimmune disease, patients using aminoglycosides or those with a history of allergy to the toxin ${ }^{31}$.

Supported by the pain syndrome theory and temporomandibular disorders ${ }^{32}$ and knowing that the use of botulinum toxin promotes muscle relaxation, reducing muscle hyperactivity and therefore a decrease in pain $11,30,33-$ 34 , the application of BTX-A has been indicated as an effective therapeutic approach for orofacial pain and TMD without systemic or permanent side effects.

Thus, the purpose of this case report was to evaluate the effectiveness of botulinum toxin as an adjuvant treatment for temporomandibular dysfunction and facial muscle aches.

\section{CASE REPORT}

A 55-year-old female patient complained of strong headaches in the last 10 years, pressure in the eyes, pain and fatigue in the masseter muscle, ringing in the ears, difficulty opening her mouth, lack of restful sleep because of severe headaches, severe wear and fractures of the lower teeth due to bruxism, loss of occlusal vertical dimension $(O V D)$, severe bruxism, excessive irritability, tiredness and depression because of strong and constant headaches.

Her medical history included two surgical procedures in one year for the excision of a supraorbital osteoma on left side (Figure $1 \mathrm{~A}$ and $\mathrm{B}$ ) and the other for the placement of an aneurysm clip (Figure 1C). Both procedures required the displacement of the temporal and frontal muscles for access, which probably caused muscle imbalance and, consequently, her headaches increased to an unbearable level. She reported having undergone many different treatment approaches by different health professionals, including bite-raising appliances, different anti-inflammatory drugs, muscle relaxants, painkillers, all of which unsuccessful.
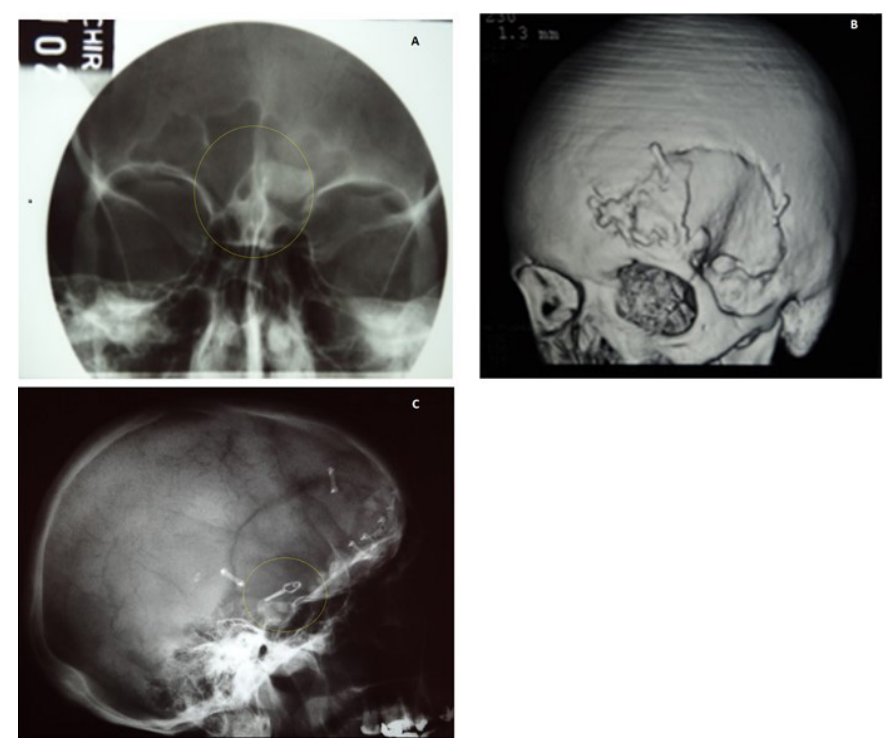

Figure 1. (A) Osteoma before surgery; (B) 3D Reconstruction in lateral position; (C) Placement of the aneurysm clips in lateral position view.

The RDC/TMD axis I questionnaire was applied as part of the diagnosis process and the patient was also 
referred to a neurologist to rule out any post-surgical nerverelated complications that she might have developed as sequelae.

Treatment options were discussed with the patient and a joint decision was made to BTX-A applications. The patient signed an informed consent form prior to starting treatment. BTX-A (Dysport 500U) was reconstituted in 1 $\mathrm{ml}$ of sterile $0.9 \% \mathrm{NaCl}$ solution and maintained at 2-8 degrees centigrade until injected in the temporal (25U) and masseter (50U) muscles bilaterally in the region of greatest muscle mass because of muscular hyperactivity. Following application, the patient was instructed regarding possible side effects and was encouraged to rest for the first 4 hours avoiding massaging the injection site.

In the second week after the BTX-A application, a hard clear acrylic bite-raising appliance was fitted and the patient was instructed to using hot compresses for 20 minutes at least three times a day, keeping to a liquid and / or soft diet taking care not to open her mouth too wide. After the fourth week of treatment, cervical stretching exercises were introduced, combined with mandibular movement coordination exercises and cognitive behavioral therapy. The patient was monitored with regards to pain using the visual analog scale (VAS) to measure pain intensity on days $0,3,5,30,60$ and 90 following administration of BTX-A.

Based on data obtained from the RDC questionnaire, the patient was classified as having muscular and joint TMD secondary to parafunction (bruxism), with limited mouth opening and disc displacement with reduction. Based on the pain scale, the patient reported the highest pain intensity (10) and that after 5 days of BTX-A application, a slight improvement was reported (8). After 30 days, a significant improvement was observed with pain reported at level 4 , however the greatest improvement was noted after 60 and 90 days when the patient reported no pain at all (0) (Figure 2).

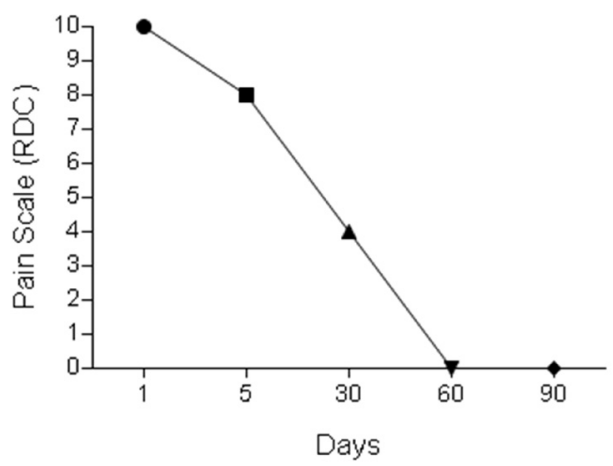

Figure 2. Evolution of pain perception after the application of TBX-A.
The patient also reported improvement in quality of sleep and a return to her normal diet. She was, however advised to avoid opening her mouth too wide and to continue with all her daily exercises at least three times daily.

After 12 weeks of treatment, exercises were intensified aiming at strengthening her muscles of mastication, with the patient still free of pain, which permitted the preparation and fitting of a snap-on prosthetic appliance (Figure 3A and B) to recover her OVD, which had been lost to tooth wear. Her occlusal splint was adjusted and the patient instructed to wear it only to sleep every other day.
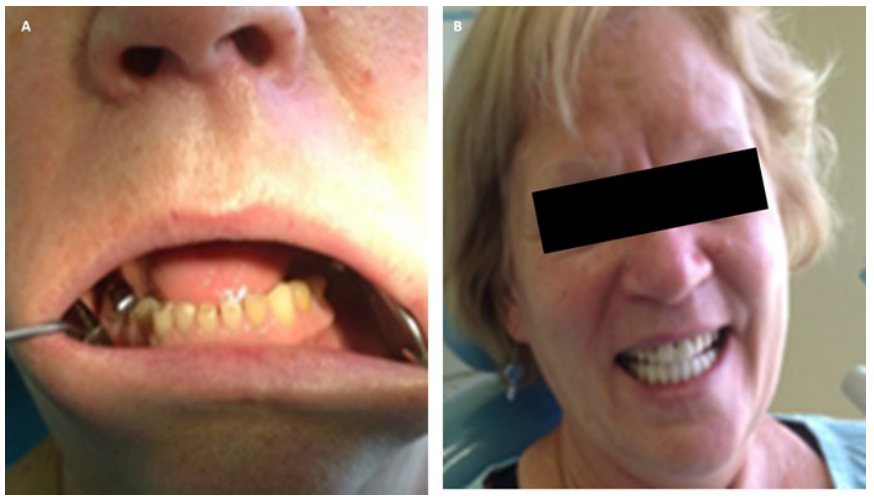

Figure 3. (A) Initial photo of patient's oral cavity before treatment. (B) Photo after prosthetic rehabilitation.

\section{DISCUSSION}

Many treatment modalities for pain secondary to hypertrophy of the muscles around the TMJ, such as muscle stretching exercises to improve mouth opening, physiotherapy, acupuncture and ultrasound have been used with varying degrees of success. Botulinum toxin has shown effectiveness in orofacial pain from musculoskeletal disorders ${ }^{35}$. The local effect of BTX-A injected into the muscle is blocking muscles innervation consequently inhibiting acetylcholine release. This will weaken the target muscle, reducing contractility and dystonic movements. This effect is permanent in the neural plate, however, with time (3 to 4 months), recovery of neuromuscular function may occur due to the sprouting of new nerve endings from the original nerve, which will bypass the blocked neuromuscular region ${ }^{36}$.

Analgesia is not the result of muscle paralysis alone, but also from chemical neurolysis and anti-inflammatory effects $^{20}$. The feeling of decreased pain persists even 
after the sensation of muscle relaxation has disappeared and in some patients the analgesic effect persists after the average period of action of the toxin. Improvement, therefore, comes from both relaxation and local action through breakage of the chronic pain cycle.

The specificity of BTX-A to cholinergic neurons in the presence of specific receptors causes it to also inhibit other neurotransmitters, like norepinephrine in motor nerves as well as adrenaline, noradrenaline, bringing additional benefits in terms of pain relief. BTX-A also suppresses the release of substance $P$, a neuropeptide involved in neurogenic inflammation and in the genesis of pain disorders, as well as the release of glutamate, another neurotransmitter involved in peripheral nociception, acting on the dorsal horn of the spinal cord17,37-38.

Pain management was deemed successful in the patient reported, due to the initial application of BTX-A, which played an important role in encouraging the patient to adhere to the treatment plan proposed, since her past experience with numerous unsuccessful attempts to resolve her severe headaches and facial pain had rendered her reluctant to see long treatment approaches through. Irritability and depressive symptoms were the result of strong constant pain and sleepless nights. As a result of the proposed treatment, early improvement in mouth opening was achieved, which permitted impressions to be taken for an occlusal splint and also to restore the balance of her stomatognathic system much more quickly. Other studies have reported success with the use of BTX-A for

\section{REFERENCES}

1. De Leeuw R. Dor orofacial: guia de avaliação, diagnóstico e tratamento. 4ª ed. São Paulo: Quintessence; 2010.

2. Dall'Antonia M, Netto Oliveira RM, Sanches ML, Guimarães AS. Dor miofascial dos músculos da mastigação e toxina botulínica. Rev Dor. 2013;14(1):52-5.

3. Sessle BJ. Acute and chronic craniofacial pain: brainstem mechanisms and nociceptive transmission and neuroplasticity, and their clinical correlates. Crit Rev Oral Biol Med. 2000;11(1):57- 91

4. Acosta-Órtiz R, Schulte JK, Sparks S, Marsh W. Prediction of different mandibular Activities by EMG signal levels. J Oral Rehabil. 2004;31(5):399-405. doi: 10.1111/j.13652842.2004.01251.x

5. Okeson JP. Tratamento das desordens temporomandibulares e oclu $\neg$ são. São Paulo: Artes Médicas; 2000.

6. Zarb GA, Carlsson GE, Sessle BJ, Mohl ND. Disfunções da articulação temporomandibular e dos músculos da mastigação. São Paulo: Santos; 2001 pain relief 23,39

It is paramount to definitively pinpoint specific causative factors in order to effectively manage patients with pain. In this case, myofascial pain was part of muscular TMD, which is a rather challenging condition to diagnose and treat. Initial therapeutic options should be minimally invasive, reversible and conservative (Machado et al., 2012). Botulinum toxin application is mildly invasive and reversible after 4-5 months, with few side effect, thus making it an excellent option in dentistry and, in particular, TMD patients.

\section{CONCLUSION}

BTX-A is herein presented as viable alternative approach for patients suffering from TMD pain syndrome, since it was shown to be effective in controlling chronic facial pain associated with muscle hyperactivity, due to its powerful muscle relaxation properties and consequent decreased muscle contracture.

\section{Collaborators}

MAU HUAMANI, NS ARAUJO and MH NAPIMOGA, conceptualization. MAU HUAMANI, NS ARAUJO, formal analysis. MAU HUAMANI, methodology. MAU HUAMANI, LA MOREIRA, NS ARAUJO, MH NAPIMOGA and ME MIRANDA, writing - review \& editing.

7. Machado E, Dos Santos LZ, Custódio LG, Cunali PA. Botulinum toxin for treating muscular temporomandibular disorders: a systematic review. Dental Press J Orthod. 2012;17(6):167-71. doi: 10.1590/S2176-94512012000600029

8. Kato MT, Kogawa EM, Mikaela, Santos CN, Conti PCR TENS and low-level laser therapy in the management of temporomandibular disorders. J Appl Oral Sci. 2006;14(2):1305. doi: 10.1590/S1678-77572006000200012

9. Oliveira JSM, Silva NP, Silva NP, Silva AP. Influence of physical therapy intervention in the temporomandibular joint dysfunction in children with chronic oral breathing. Fisioter Bras. 2012;13(1):69-75

10. Pal US, Kumar L, Mehta $G$, Singh $N$, Singh $G$ SingH $M$, et al. Trends in management of myofacial pain. Natl J Maxillofac Surg. 2014:5(2):109-16. doi: 10.4103/0975-5950.154810

11. Freund $B$, Schwartz $M$. The use of botulinum toxin for the treatment of temporomandibular disorder. J Oral Maxillofac Surg. 1999;57(8):916-20. Doi: 10.1016/S0278-2391(99)90007-

12. Blitzer A, Sulica L. Botulinum toxin: basic science and clinical uses in otolaryngology. Laryngoscope. 2001;111(2):218-26. doi: 


\section{$10.1097 / 00005537-200102000-00006$}

13. Bentsianov B, Zalvan C, Blitzer A. Noncosmetic uses of botulinum toxin. Clin Dermatol. 2004;22(1):82-8

14. Silva LCM, Neves RF. Respostas clínicas no uso da toxina botulínica para o tratamento da dor crônica musculoesquelética: uma revisão da literatura. Rev Dor. 2007;8(3):1080-4.

15. Aoki KR, Francis J. Updates on the antinociceptive mechanism hypothesis of botulinum toxin A. Parkinsonism Relat Disord. 2011 Nov;17 Suppl 1:S28-33. doi: 10.1016/j.parkreldis.2011.06.013

16. Sposito MMM. Toxina botulínica do tipo A: mecanismo de ação. Acta Fisiátrica. 2009;16(1):25-37.

17. Aoki Kr. Evidence for antinociceptive activity of botulinum toxin type A in pain management. Headache. 2003;43:59-15.

18. Morenilla-Palao C. Regulated exocytosis contributes to protein kinase $C$ potentiation of vanilloid receptor activity. J Biol Chem. 2004;279-282. doi: 10.1074/jbc.M311515200

19. Casale R, Tugnoli V. Botulinum toxin for pain. Drugs RD. 2008;9(1):11-27.

20. Gazerani P, Pedersen NS, Staahl C, Drewes AM, Arendt-Nielsen L. Subcutaneous botulinum toxin type A reduces capsaicininduced trigeminal pain and vasomotor reactions in human skin. Pain. 2009;141(1-2):60-9. doi: 10.1016/j.pain.2008.10.00

21. von Linder JJ, Niederhagen B, Bergé S. Type A botulinum toxin in the treatment of chronic facial pain associated with masticatory hyperactivity. J Oral Maxillofac Surg. 2003;61(7):774-8. doi: 10.1016/S0278-2391(03)00153-8

22. Ernberg M, Hedenberg-Magnusson B, List T. Efficacy of botulinum toxin type $A$ for the treatment of persistent myofascial TMD pain: a randomized, controlled, double-blind multicenter study. Pain. 2011;152(9):1988-96. doi: 10.1016/j.pain.2011.03.036

23. Guarda-Nardini L, Manfredini D, Salamone M, Salmaso L, Tonello S, Ferronato G. Efficacy of botulinum toxin in treating myofascial pain in bruxers; a controlled placebo pilot study. Cranio. 2008;26(2):126-35.

24. Guyer BM. Mechanism of botulinum toxin in the relief of chronic pain. Curr Rev Pain. 1999;3(6):427-31.

25. Purkiss J, Welch M, Doward S, Foster K. Capsaicin-stimulated release of substance $P$ from cultured dorsal root ganglion neurons: involvement of two distinct mechanisms. Biochem Pharmacol. 2000;59(11):1403-6. doi: 10.1016/S00062952(00)00260-4

26. Ishikawa H, Mitsui $Y$, Yoshitomi T. Presynaptic effects of botulinum toxin type a on the neuronally evoked response of albino and pigmented rabbit iris sphincter and dilator muscles. Nippon Ganka Gakkai Zasshi. 2001 Apr;105(4):218-22.
27. Morris JL, Jobling $P$, Gibbins IL. Differential inhibition by botulinum neurotoxin $A$ of cotransmitters released from autonomic vasodilator neurons. Am J Physiol Heart Circ Physiol. 2001 Nov;281(5):H2124-32.

28. Cui M, Li Z, You S, Khanijou S, Aoki KR. Mechanisms of the antinociceptive effect of subcutaneous Botox@: inhibition of peripheral and central nociceptive processing. Naunyn Schmiedebergs Arch Pharmacol. 2002;365(Suppl 2):17.

29. Jankovic J, Orman J. Botulinum A toxin for cranial-cervical dystonia: a double- blind, placebo controlled study. Neurology. 1987;37(4):616- 23.

30. Lindern JJ. Type A botulinum toxin in the treatment of chronic facial pain associated with temporomandibular dysfunction. Acta Neurol Belg. Bruxelles. 2001 Mar;101(1):39-41.

31. Mor N, Tang C, Blitzer A. Temporomandibular Myofacial Pain Treated with Botulinum Toxin Injection. Toxins (Basel). 2015;7(8):2791-800. doi: 10.3390/toxins7082791

32. Travell J, Rinzler S, Herman M. Pain and disability of the shoulder and arm. Treatment by intramuscular infiltration with procaine hydrochloride. J Am Med Assoc. 1942;120(6):417-422.

33. Cheshire WP, Abashian SW, Mann JD. Botulinum toxin in the treatment of myofascial pain syndrome. Pain. 1994;59(1):65-9.

34. Tommasi AF. Diagnóstico em patologia bucal. $2^{\mathrm{a}}$ ed. [SI]: Pancast Editorial; 1997.

35. Sunil SM, Babu BG, Deepthi S, Veerabhadrappa AC, Vadavadagi $S V$, Punde P. Botulinum toxin for the treatment of hyperfunctional lines of the forehead. J Int Soc Prev Community Dent. 2015 Jul-Aug;5(4):276-82. doi: 10.4103/2231-0762.161227.

36. Dutton JJ. Botulinum-A toxin in the treatment of craniocervical muscle spasms: short and long- term, local and systemic effects. Surv Ophthalmol. 1996;41(1):51-65.

37. Dressler D, Saberi FA, Barbosa ER. Botulinum toxin: mechanisms of action. Arq Neuropsiquiatr. 2005;63(1):180-5. doi: 10.1590/ S0004-282X2005000100035

38. Colhado OCG, Boeing M, Ortega LB. Toxina botulínica no tratamento da dor. Rev Bras Anestesiol. 2009;59(3):366-81.

39. Fallah HM, Currimbhoy $S$. Use of botulinum toxin $A$ for treatment of myofascial pain and dysfunction. J Oral Maxillofac Surg. 2012;70(5):1243-5. doi: 10.1016/j.joms.2012.01.015

Received on: 29/3/2016 Final version resubmitted on: 2/9/2016 Approved on: 21/9/2016 